\title{
Multiple-Way Effect of Ownership Factor in the Catch-up of the Latecomers of Enterprises in China Telecom Manufacturing
}

\author{
Chang Yaozhong \\ Institute of Industrial Economics Chinese Academy of Social Sciences, Beijing 100088, China \\ yzhchang@263.net
}

\begin{abstract}
Present researches on ownership of latecomers of enterprises in technology catch-up pay little attention to indirect influence of ownership on latecomers through industry-schoolinstitute-user platform and market buyer's power. In this research, resource dependence theory and corporation governance theory are combined to do time-series analysis in case study of thirty-year technology catch-up process of five telecom manufacturers. Research shows following results. First, Ownership factor could exert multipleway effect which could influence the technology catch-up of latecomers through power of government, buyer and industry platform. Second, ownership factor could reinforce or break alignment effect (1) formed among enterprises' technical resource structure, capability development action and innovation capacity performance. Third, State ownership exerted leading function in industry technology innovation, but private ownership favor independent technology innovation. Suggestions are provided here. First, enterprises should avoid trap of external resource dependence and place emphasis on long-term capability building. Second, state assets administration department should manage visibility scientifically. Third, government should fully exert innovation support function of industrial platform and make use of buyer's power carefully. This paper forms logic analysis framework of integrated theories, and develops external control perspective of resource dependence theory and visibility perspective of corporation governance.
\end{abstract}

Index Terms - Technology innovation capability, external resource dependence, principal-agent relationship, visibility

\section{Introduction}

Probe of technology development route and innovation capability evolvement of latecomer of enterprises helps to reveal technology catch-up mechanism of microeconomic main bodies in developing countries. Some researchers studied and summarized route and mode of catch-up of latecomers, and discussed collaboration in part of industrial trains such as industry, school and institute [1] [2] [3] [4] [5] [6]. But there are research gaps that different ownership structures of enterprises lead to differences in resource structure, dynamic mechanism, development mode and innovation performance in their technology development. And mainstream enterprise management theories were not fully applied in them. Other researchers paid attention to heterogeneity of ownership and explored difference in governor's attitude in innovation, environment strategy, development strategy, technology capability cultivation and technology innovation route led by it [7] [8] [9] [10] [11]. But there are research gaps that field of vision on ownership has not been extended to external organizes who provide key resources to the researched one. Complicated dependence relations based on network level [12]
[13] lacks analysis, which lead to shortage of research on multiple way function mechanism of ownership through government-industry-school-institute-buyer and underestimate of influence of ownership factor on enterprises' technology development decision.

As technology and knowledge intensive industry, telecom manufacturing possesses high attention rate in its ownership and industry chain, and its phenomenon of technology catchup is typical. The technology catch-up process of telecom manufacturing which is usually in debate is used as research object, and logic analysis framework of integrated theories which combines external control perspective of resource dependence theory and visibility perspective of corporation governance are constructed here. Time series analysis on case study of the thirty-year catch-up process of five telecom manufacturing latecomers is done, in which ownership of government-industry-school-institute-buyer who providing key resource to latecomers is taken into consideration. Complicated influence mechanism of ownership on resource structure and technology development decision of latecomers is analyzed, and function of ownership factor on performance of technology catch-up and innovation capacity is evaluated.

\section{Theoretical Background}

\section{A. Technology Capability and Technology Innovation Capability}

Technology capability is one kind of capability to put technology to usage, is a determinant factor of industrial competitive power [14] [15] [16]. During introduction phase, latecomers of enterprises acquire technology and make usage. The technology capability in this phase is mainly static [17]; In imitation phase, latecomers could improve present technology [18] [19]; In innovation capability construction phase, some enterprises could identify effective utilization opportunities of technology, extend and deepen its own capability or selectively use present technology to develop their own capability. The technology capabilities in the two latter phases are dynamic [20]. To sum up, technology capability include static capability acquired in introduction and put to usage, and dynamic capability acquired in imitation, improvement and innovation and put to technical innovation.

\section{B. Visibleness of Capital}

Itami and Roehl considered good corporation performance come from capital which can't be purchased directly from market and need be cultivated and developed in business 
operation [21]. Jiang etc. indicated that as invisible capital, technology innovation capability's establishment, compared with resource acquirement, is an activity with low visibleness [11]. Visibleness of invisible capital shows two-dimension characters in shape and time. For visibleness, more easy to be identified and more possible to happen recently, more to be high.

\section{Visibility Perspective of Corporation Governance}

Corporation governance structure is a kind of system arrangement of authorization and its restriction to solve principal-agent problem [22]. Jensen and Meckling indicated that core problem of corporation governance is information dissymmetry [23]. Jiang etc. considered visibility to be degree of appreciation on organization action by shareholder or official who are short of enterprise-specific understanding and detached from enterprise operation [11]. These governors of state enterprise essentially are officials who are inclined to activity with high visibility and ignore activity with low visibility. Tylecote and Ramirez argued that state enterprise managers are responsible for senior officials who are not principal, and two-rank agent deepens distort of activity result, which lead to low visibility of direct output and high visibility of cost for R\&D activity [24]. After analysis, it can be known that visibility of agent's operation activity is evaluation of principal on this activity, and visibility of principal is influenced by information dissymmetry, visibleness and specific preference of capital.

\section{External Control of Organization of Resource Dependence Theory}

Pfeffer and Salancik considered that an organization can't control all needed resources and needs other organizations to provide much resources, and it's pivotal to acquire and maintain resource to survive [25]. Casciaro and Piskorski explained organization relation with two dimensions. In power imbalance dimension, the higher-power actor find it easier than the lower-power actor to dictate the terms of relationship by threatening to withdraw from the exchange; In mutual dependence dimension, while under high mutual dependence, uncertainty and potential cost will promote long-term contract (joint venture or consolidation) to ensure provision of critical resources; Under simultaneous exist of power imbalance and mutual dependence, the higher-power actor dislikes constraint absorption for fear of losing advantage, but still rely on resources provided by the lower-power actor, which will lead to obstacle to get to exchange agreement [13]. In summary, this perspective describes how enterprises use tactics to reduce uncertainty of critical external resources for their surviving and development, and the final agreement and the form and effect of established organization are determined by power comparison of two actors.

\section{Research Method}

\section{A. Case Study}

Multiple-case study obeys replication logic [26]; Diversiform sources of data are suggested to construct evidence-triangle [27] which is realized here by collecting data from internal interview, field research, year book, public government bulletin, enterprises' website and publication, corporation annual report and social responsibility report, consultant report, news and comment, book and article etc.; Considering complicated causality which can't be dealt with by available simple logic framework [11], constructive explanation method [26] is used to construct logic analysis framework of integrated theories.

\section{B. Research Steps}

They are case collection, case grouping, affair ordering, phase partition, framework construction, relation carding, case replication, phase evaluation. Time series analysis on chronicle of events [26] is adopted to do 30-year longitudinal design and array, in which the logic analysis framework is used to analyse causality of events and explain technology innovation capacity movement in time series.

\section{Research Cases}

Five selected telecom manufacturers are Shanghai Bell, China Potevio, Datang telecom, Zhongxin Communication, Huawei Technology, whose operation revenues listed in Fig.1.

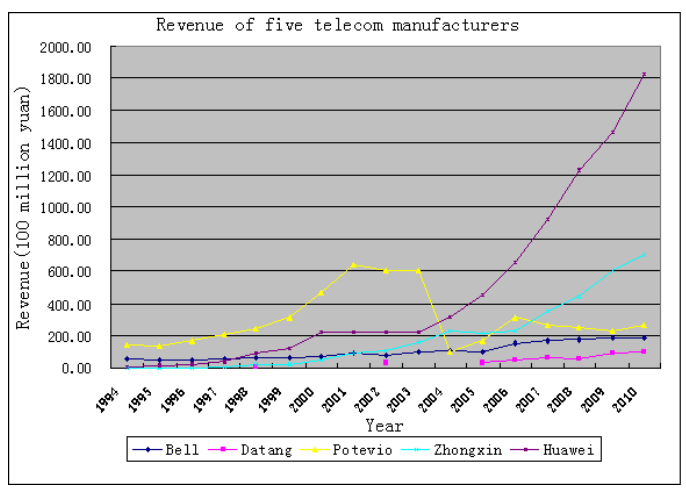

Source: Collative data of corporation annual report and social responsibility report, and statistics from state assets administration committee, etc.

Fig. 1 Annual revenue of five telecom manufacturers

TABLE I Fundamental state of five telecom manufacturers in 2010

\begin{tabular}{|l|l|l|l|l|l|l|}
\hline Company & Ownership & $\begin{array}{l}\text { Founded } \\
\text { Year }\end{array}$ & $\begin{array}{l}\text { Total Assets } \\
\text { (billion yuan) }\end{array}$ & Employee & $\begin{array}{l}\text { Revenue } \\
\text { (billion yuan) }\end{array}$ & NPR* \\
\hline Bell & Joint-venture & 1984 & 25.27 & 11014 & 18.18 & $1.60 \%$ \\
\hline Datang & State-owned & 1957 & 24.41 & 12000 & 10.03 & $2.10 \%$ \\
\hline Potevio & State-owned & 1932 & 23.59 & 23000 & 26.60 & $1.00 \%$ \\
\hline Zhongxin & $\begin{array}{l}\text { State-hold } \\
\text { Individually-run }\end{array}$ & 1985 & 84.15 & 85232 & 70.26 & $4.60 \%$ \\
\hline Huawei & Individually-run & 1987 & 160.84 & 111800 & 185.18 & $12.80 \%$ \\
\hline
\end{tabular}

Source: Corporation annual report and social responsibility report, official website and statistics from state assets administration committee, etc. Note: *NPR means net profit rate. 


\section{Research Clues}

Public digital program controlled switching system (call "System A" below) and cellular mobile communication system (call "System B" below) are taken as two research clues, which are important telecom equipment with high requirement on performance, quality, technology and stability.

\section{E. Phase Partition}

According to level of technology innovation capacity of latecomers and government policy guide on technology development, process of technology catch-up is divided to three phases. Production Localization Phase (1980s): By ways of joint venture and joint operation, product and technology were introduced, and technology was assimilated and absorbed. Independent Research and Development Phase (1990s): Based on introduction, assimilation and absorbing of introduced technology, through localized innovation and improved innovation, latecomers mastered capacity of designing and developing, and developed product with their own technology and brand; Core Capacity Phase (2000s): Advanced local enterprises broke through bottleneck and mastered core technology, and brought other enterprises to breach technology bottleneck.

\section{F. Logic Framework}

Resource restricts scope of action of enterprises, and governance stimulates direction of enterprises' action.

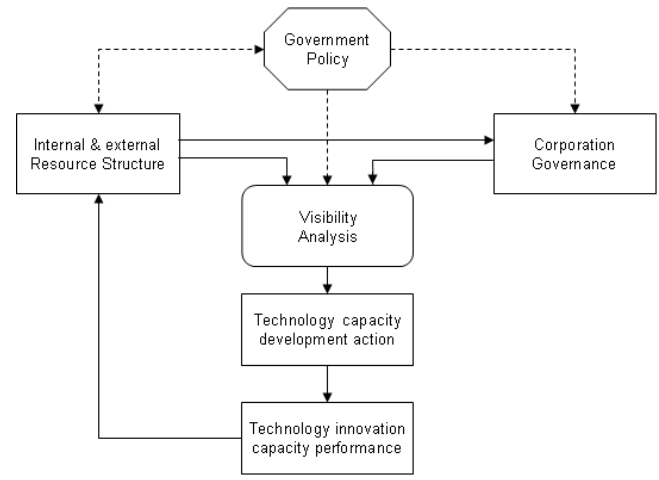

Fig. 2 Logic analysis framework of technology innovation capacity development

i) Structure of internal and external resource: Casciaro and Piskorski deemed that organization will seek to reduce risk from critical external resources and decrease power imbalance by ways of long-term contract, purchasing each other's shares or consolidation [13]. Wei indicated that Chinese enterprises influence the process of policy making and implementation of government, in order to acquire favorable market environment [28]. ii) Corporation governance structure: State-owned enterprises adopted government-dominant governance mode, with weaker internal governance and stronger external governance [22], and there is often information dissymmetry problem. iii) Government Policy: Under government-dominant governance mode, state-owned enterprises carry out and implement state policy in operation, which is also means for government to intervene and participate in economy [29]. iv) Visibility: Stimulation and restriction system will urge manager or entrepreneur to choose technology development mode with high visibility of principal, especially in stateowned enterprises. v) Technology capacity development action: It's technology capacity development conduct of enterprises to increase technology capability (static or dynamic capacity), such as joint venture and joint operation with foreign companies, independent research and development and accumulation, intercourse and cooperation within industryschool-institute-user platform, study in employ, etc..

\section{G. Evaluation Method}

1) Ownership Factor and Technology Catch-up Performance: Qualitative evaluation is major and quantitative evaluation is assistant. Technology catch-up performance describes effect of shortening distance of technology between forthgoer and latecomer.

TABLE II Evaluation indexes: ownership factor and technology catch-up performance

\begin{tabular}{|c|l||l|l|}
\hline \multicolumn{2}{|c||}{ (State) ownership factor } & \multicolumn{2}{|c|}{ Technology catch-up performance } \\
\hline EV & $\begin{array}{l}\text { Criterion: } \\
\text { Stock owner } \\
\text { (manager appointment and origin)* }\end{array}$ & EV & $\begin{array}{l}\text { Criterion: } \\
\text { Product appearing order; } \\
\text { Industry promotion; } \\
\text { Competition power advance }\end{array}$ \\
\hline 1 & $\begin{array}{l}\text { Private or collective holding (enterpriser } \\
\text { appointed by stockholder and not from state } \\
\text { system) }\end{array}$ & 1 & No item prominent \\
\hline 2 & $\begin{array}{l}\text { State relative holding (enterpriser appointed by } \\
\text { stockholder and from state system) }\end{array}$ & 2 & One item prominent \\
\hline 3 & $\begin{array}{l}\text { State absolute holding (some managers } \\
\text { appointed by government and from state } \\
\text { system) }\end{array}$ & 3 & Two items prominent \\
\hline 4 & $\begin{array}{l}\text { Owned by state (managers appointed by } \\
\text { government and being officials) }\end{array}$ & 4 & $\begin{array}{l}\text { Three and above items } \\
\text { prominent }\end{array}$ \\
\hline
\end{tabular}

Note: 1) EV is abbreviation of evaluation, the same in below tables. 2) 1-4 means lowest, lower, larger, largest. 3) *In criterion column, content out of brackets is major reference, and those in brackets are assistant reference.

2) Structure of Internal and External Resource, Action of Technology Capacity Development and Performance of Technology Innovation Capacity: Performance of technology innovation capacity describes degree of advance of technology innovation capacity of latecomers. 
TABLE III Evaluation Indexes: Structure of internal and external resource, action of technology capacity development and performance of technology innovation capacity

\begin{tabular}{|l|l||l|l||l|l|}
\hline \multicolumn{2}{|c||}{$\begin{array}{l}\text { Structure of internal and external technical } \\
\text { resource }\end{array}$} & \multicolumn{2}{c||}{ Technology capacity developing actions } & \multicolumn{3}{c|}{ performance of technology innovation capacity } \\
\cline { 2 - 5 } EV1 & $\begin{array}{l}\text { Criterion: Degree of resource } \\
\text { dependence }\end{array}$ & EV2 & $\begin{array}{l}\text { Criterion: Number of types of } \\
\text { main actions }\end{array}$ & EV3 & $\begin{array}{l}\text { Criterion: Technology capacity structure(Technology } \\
\text { source and IPR adscription) }\end{array}$ \\
\hline 4 & Joint venture with foreign company & 1 & One & 1 & Static(technology introduction, no IPR) \\
\hline 3 & Project cooperation (participation) & 2 & Two & 2 & Mainly Static(local innovation, some IPR) \\
\hline 2 & Project cooperation (dominance) & 3 & Three & 3 & Mainly dynamic(cooperation-development, share IPR) \\
\hline 1 & Own platform & 4 & Four above & 4 & Dynamic(Independent-development, own IPR) \\
\hline
\end{tabular}

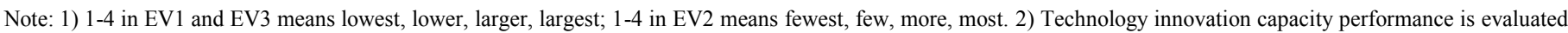

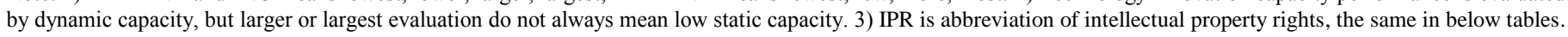

\section{Research Result}

\section{A. Product Localization Phase (1980s)}

1) Phase Background: i) Industrial Background: Early 1980s, China's public switching equipment was sill using stepby-step telephone system and crossbar telephone exchange system which were used by advanced countries in 1940s and 1950s, and western countries had started to deploy digital program controlled switching system. Behindhand technology and equipment severely restricted development of telecommunication [30]. ii) Policy Background: In 1979, Deng Xiaoping put forward strategy of communication antecedence. But introduction of large quantities of foreign products brought great competition pressure on domestic products. Consequently, China government started to emphasized policy as "combination of technology and trade" and "exchange market for technology", and introduced technology and realized domestic production. iii) System Characteristics: Ministry of Posts and Telecommunication (Abr. P\&T) administrated huge industry, schools, institutes and operators within state P\&T system mainly by administration and planning mode. Under planning economy, R\&D, production and supply-assignment were divided to institute, factory and material management bureau [31].

2) Case Analysis: i) Shanghai Bell (Abr. SBell): As China-Foreign joint venture, SBell afforded responsibility of technology introduction. Its resource combination was market monopoly buyer power (Ministry of P\&T), industry-schoolinstitute-user platform (Abr. Platform below) and management and technology of foreign company, which led to tendency of dependence on technology introduction. SBell went into technology development channel of "introductionassimilation-absorb-localization", in which SBell emphasized raising static capacity but ignored raising dynamic capacity. This action enhanced reliance on technology introduction. Industry-school-institute-user cooperation had double functions in reducing dependence and intensifying current mode. ii) Potevio: As Industry Corporation, Potevio was weak in $R \& D$ capacity, but could fully make use of the platform to study advanced technology. According to policy of "assimilate, absorb, independent design and manufacture", Potevio assimilated and absorbed introduced technology by researching and developing low-end product by cooperation with domestic institutes out of P\&T system, and went into technology development channel of "assimilate, absorb and cooperation-develop". This channel did favor for developing static capacity and limited dynamic capacity. Industry-schoolinstitute-user cooperation in P\&T system reduced dependence on foreign technology resource, and market monopoly buyer's power enhanced present mode. iii) Datang: As institute, Datang had strong R\&D capacity and could make full use of platform resources to study advanced technology. According to policy of "assimilate, absorb, independently design and manufacture", Datang assimilated and absorbed introduced technology by researching and developing low-end product independently, and went into technology development channel of "assimilate, absorb, independently R\&D" which did favor for developing dynamic capacity. Industry-school-instituteuser cooperation in P\&T system intensified technical independence, and market monopoly buyer power enhanced present mode. iv) Zhongxin and Huawei: Zhongxin is a stateholding and individually-run company, and Huawei is a private company. These two individually-run enterprises could not rely on platform resource and buyer's power, and had no opportunity to introduce technology by building joint venture, which determined the feasible way of independent R\&D activity to develop their own technology and making full use of every possible way to study technology. They went into development channel of "opening study, independent R\&D", which, though slow, was helpful to cultivate dynamic capacity of technology innovation and also technology in production and service.

\section{B. Independent Development Phase (1990s)}

1) Phase Background: i) Industrial Background: Product from joint-venture lowered market price but there were still no independent intellectual property rights. For mobile communication, " 1 st generation was thoroughly lost, $2^{\text {nd }}$ generation was missed too" [32]. ii) Policy Background: Because of no independent innovation and grown-up of local industry, policy of "exchange market for technology" was queried to be invalid. Based on policy dynamics, under condition of increase of negative effect of production localization strategy and increase of innovation capacity of domestic latecomers, government would transform policy from localization promotion policy to independent development promotion policy. From 1993 to 1998, China 
government implemented a series of measures such as increasing market share of independently developed products, improving capacity of independent development and innovation, promoting combination of industry-schoolinstitute-user, and breaching monopoly telecom operation by P\&T system, etc.. iii) System character: During 1990s, Potevio was detached with Ministry of P\&T and became central government owned enterprise, which means Potevio was transformed from P\&T Industry Corporation to enterprise group adapted to market economy [31]; P\&T institutes were also reformed to enterprises to be adapted to market. Administrative mode, combination of "usage, scientific research and production" became ineffective while confronting benefit mechanism. But old system still restricted state-owned corporations to build function of scientific research and sale in human resource, financing and capacity [31]. Ministry of Information Industry (containing original Ministry of P\&T) had only weakened market buyer's power.

2) Case Analysis: i) SBell: Under resource structure of weak innovation capacity, single product, weakened platform resource and market buyer's power, independent development promotion policy prompted joint venture to do limited innovation in current product and some derivative innovation, but couldn't push them out of existing technology development channel. Restructure and transferring stock strengthened new technology introduction from foreign parent company, which led to missing of opportunity to develop its own new product and technology. Then the technology innovation capability was hard to be advanced. The Platform promoted opening study and reduced reliance on external technology, but market buyer's power strengthened present development mode. ii) Potevio: Under independent development policy, its present resource structure intensified inclination to rely on cooperation with domestic institute to develop new products. This mode promoted static capacity and limited dynamic capacity. Potevio continued to go along development channel of "assimilate, absorb and develop by cooperation" and relied on technology cooperation. Cooperation within the platform of P\&T system boosted opening study, weakened reliance on current $R \& D$ partner, and market buyer's power strengthened present technology development mode. iii) Datang: Under independent development policy, its present resource structure intensified present independent R\&D mode assisted by study in cooperation. Datang continued to go along development channel of "assimilate, absorb, independently R\&D" and raised its independence in technology development. Opening study through cooperation within the platform of P\&T system promoted independent development capability, and market buyer's power strengthened present technology development mode and industrialization technology in production. iv) Zhongxin and Huawei: Individually-run enterprises lacked stable external resources such as direct connection with the platform, and they had to go along present development channel of "opening study, independent R\&D". They insisted independent development and opening study, and continuously raise dynamic technology innovation capacity. Independent development promotion policy improved their market environment and was helpful to form fine cycle of their independent development mode (2). Privately-run enterprises could also make use of technology resource of the platform indirectly to accelerate their step in technology R\&D and industrialization.

\section{Core Capacity Phase (2000s)}

1) Industry and Policy Background: i) Industry Background: Late 1990s, technology of the 3rd generation mobile communication brought forward by western countries became mature for commercial usage, but critical intellectual property rights were all mastered by western forthgoer. TDSCDMA 3rd generation standard put forward by China provided good opportunity to Chinese enterprises to innovate technology to acquire core intellectual property rights and master right of speech in standard. It's helpful to change the state that China spent tens billions of dollars to buy intellectual property rights and patent [33]. Three ministries took the lead in establishing TD Industry Alliance. ii) Policy Background: From 2000 to 2004, China government presented breaching core technology, key technology and preliminarily establishing independent innovation R\&D system. From 2005 to 2008, China government required accelerating industrial government-industry-school-institute-capital innovation system dominated by enterprises, intensifying government's R\&D investment, constructing public technical service platform and industry alliance, implementing strategy of standard and intellectual property rights, and conquering core technology [34] [35]. When independent development promotion policy couldn't help to release restriction of technology by the western, local enterprises raised their innovation and industry capability, and opportunity of forming new technology and industry appeared, China government surpassed former "introduce, assimilate, absorb, finally design independently, manufacture" policy, and transformed policy from independent development promotion to core capacity promotion. The new policy required effort to breach core technology and establish independent innovation science and technology system. iii) System Character: During period of "Ninth Five-year Plan", in information industry, separating enterprises from government management, splitting of posts from telecoms, telecom restructuring, and state-owned enterprises reforming were implemented [34]. Competition market in telecom operation had been established preliminarily, and new industry-study-institute-user platform (TD Industry Alliance) had been established.

2) Case Analysis: i) SBell: Confined by resource structure, this joint-venture got into technology development channel of "Introduce, assimilate, absorb, localize", technology capacity was under foreign company's control, and new product releasing was impeded. Government's core capacity promotion policy prompted it to change development channel and to do independent innovation and master key technology. Opening industry-school-institute-user platform 
reduced dependence on technology introduction, and core capacity promotion market buyer's power was in favor of breaching former development mode. ii) Potevio: Under core capacity promotion policy and based on integrated enterprise resource, Potevio went out of former technology development channel of "assimilate, absorb, develop by cooperation" and entered channel of "introduce by cooperation, assimilate, independently develop". Potevio introduced core basic technology from Datang in the platform and developed its own application technology and product. This new mode pushed cultivation of technology innovation capacity. New opening platform provided support on key technology, and core capacity promotion market buyer's power intensified new technology development mode and droved development of production and service technology. iii) Datang: Under core capacity promotion policy, according its resource structure of external source of government support and internal innovation capacity, Datang devoted itself in standard establishment, core technology development and IC design and manufacturing, and continuously improved its capacity in technology innovation and industrialization. Datang exerted leading role in industry and function of technology spill over, and pushed independent innovation of the whole industry chain. It adapted itself to new technology development channel of "independently R\&D core technology, push industrialization by cooperation". New platform promoted spill over of technology and industrialization, and core capacity promotion market buyer's power intensified new technology development mode. iv) Zhongxin: Under core capacity promotion policy and based on optimized internal and external resource structure, according to market guide mainly and policy guide secondarily, Zhongxin insisted on independent R\&D and also made use of cooperation, which continuously strengthened its independent innovation capacity to raise its competition power, increase profitability capacity and gain policy support. Opening new platform promoted study and acquirement of new technology, and core capacity promotion market buyer's power strengthen independent R\&D mode. v) Huawei: Under core capacity promotion policy and based on optimized internal and external resource structure, according to market guide, Huawei insisted on independent R\&D and also joint venture to raise innovation capacity, competition power and profitability capacity. Opening new platform promoted study and acquirement of new technology, and core capacity promotion market buyer's power strengthened independent $\mathrm{R} \& \mathrm{D}$ mode.

\section{Evaluation Result}

1) Ownership and Catch-up Performance: In Table IV, the evaluation results in three phases are listed.

TABLE IV Evaluation of ownership factor and technology catch-up performance in three phases

\begin{tabular}{|c|c|c|c|c|c|}
\hline \multirow[b]{2}{*}{ PH } & \multirow[b]{2}{*}{$\mathbf{C P}$} & \multicolumn{2}{|r|}{ (state-owned) ownership factor } & \multicolumn{2}{|r|}{ Technology catch-up performance } \\
\hline & & $\mathbf{E V}$ & $\begin{array}{l}\text { Criterion: } \\
\text { Stock owner (manager appointment and origin) }\end{array}$ & $\mathbf{E V}$ & $\begin{array}{c}\text { Criterion: } \\
\text { Product appearing order; Industry } \\
\text { promotion; Competition power advance }\end{array}$ \\
\hline \multirow{5}{*}{1} & $\mathrm{BL}$ & 3 & State-holding(chairman-official; general manager-Foreigner) & 4 & leading;big;big \\
\hline & PT & 4 & State-owned(managers being official and appointed by government) & 2 & no;no;big \\
\hline & DT & 4 & State-owned (managers being official and appointed by government) & 3 & some leading;no;big \\
\hline & ZX & 2 & State relative holding(enterpriser being initiator and coming from controller) & 2 & no;no;big \\
\hline & HW & 1 & Private or collective holding (enterpriser being initiator and private stockholder) & 1 & no;no;no \\
\hline \multirow{10}{*}{2} & \multirow{2}{*}{ BL } & \multirow{2}{*}{3} & \multirow{2}{*}{ State-holding(chairman-official; general manager-Foreigner) } & \multirow{2}{*}{2} & A:*;big;big \\
\hline & & & & & B: lagging;no;small \\
\hline & \multirow{2}{*}{ PT } & \multirow{2}{*}{4} & \multirow{2}{*}{ State-owned(managers being official and appointed by government) } & \multirow{2}{*}{2} & A:leading;no;big \\
\hline & & & & & B:lagging;no;small \\
\hline & \multirow{2}{*}{ DT } & \multirow{2}{*}{4} & \multirow{2}{*}{ State-owned(managers being official and appointed by government) } & \multirow{2}{*}{3} & A:some leading;small;big \\
\hline & & & & & B:leading;no;small \\
\hline & \multirow{2}{*}{$\mathrm{ZX}$} & \multirow{2}{*}{2} & \multirow{2}{*}{ State relative holding(enterpriser being initiator and private) } & \multirow{2}{*}{2} & A:not leading;no;big \\
\hline & & & & & B:not leading;no;big \\
\hline & \multirow{2}{*}{ HW } & \multirow[t]{2}{*}{1} & \multirow{2}{*}{ Private or collective holding (enterpriser being initiator and private stockholder) } & \multirow{2}{*}{2} & A:not leading;no;big \\
\hline & & & & & B:not leading;no;big \\
\hline \multirow{5}{*}{3} & $\mathrm{BL}$ & 2 & State share(chairman-official; general manager-Foreigner) & 2 & Not leading;no;big \\
\hline & PT & 4 & State-owned(managers being official and appointed by government) & 2 & Not leading;no;big \\
\hline & DT & 4 & State-owned(managers being official and appointed by government) & 4 & leading;big;big \\
\hline & $\mathrm{ZX}$ & 2 & State relative holding(enterpriser being initiator and private stockholder) & 3 & some leading;no;big \\
\hline & HW & 1 & Private or collective holding (enterpriser being initiator and private stockholder) & 2 & Not leading;no;big \\
\hline
\end{tabular}

Note: 1) BL, PT, DT, ZX and HW means Shanghai Bell, Potevio, Datang, Zhongxin and Huawei respectively. 2) PH, CP, EV in first two rows means Phase, Corporation and Evaluation. 3) System A is evaluation object in Phase 1; System A and System B are evaluation objects in Phase 2; System B of China's 3G standard is evaluation object in Phase 3. 4) *Shanghai Bell System A's appearance order has been considered in Phase 1. 5) "no" in the rightest column means product has not been developed or enterprise has no obvious technology spill over. 
2) Resource, Conduct and Performance: In Table V, the evaluation results in three phases are listed.

TABLE V Evaluation of Enterprise's Structure of internal and external resource, action of technology capacity development and performance of technology innovation capacity

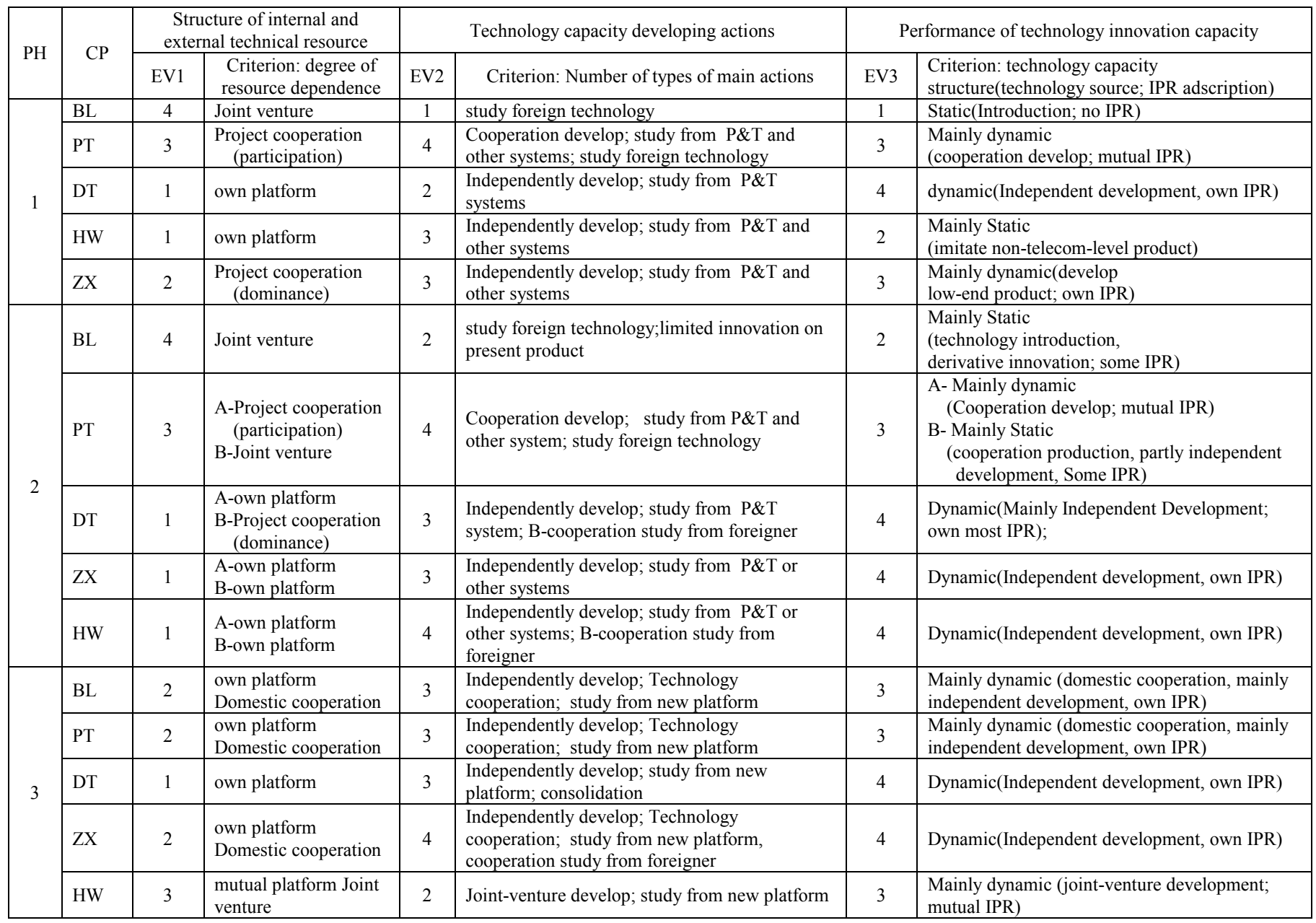

Note: 1) P\&T System here means industry-school-institute-user system of Posts and Telecoms; 2) "Own platform" means own R\&D platform; 3) Evaluation in Core Capacity Phase is mainly focused on System B of China's 3G standard.

\section{Discussion and Conclusion}

\section{A. Process Framework}

1) The technology catch-up process contains "three phases and two changes". i) In production localization phase, policy of "introduce, assimilate, absorb" was basically realized. But the joint-venture got into dependence on foreign technology when implementing the policy of technology introduction, and market monopoly buyer's power strengthened this dependence. Other latecomers benefited from spill over of technology introduction directly or indirectly, and entered channels of independent development or cooperation development. Industry-school-institute-user platform of P\&T system promoted their technology independence directly or indirectly. ii) Since domestic product thoroughly fail to compete with foreign product, "exchange market for technology" policy was queried to be invalid, which led to transformation of policy to independent development promotion. iii) Independent development policy was hard to change joint-venture's mode of dependence on foreign technology and only prompted limited localization innovation. And market buyer's power of independent development policy intensified its dependence mode. But the market buyer's power, platform and policy visibility supported and stimulated independent development activities of other state-owned corporations. Market buyer's power and platform also promoted independent innovation activities of individually-run enterprises. iv) Embarrassing situation that key technology and core intellectual property rights were heavily restricted by foreign corporation and huge quantities of fees were spent for patent and intellectual property rights, pushed policy's transition to core capacity promotion policy. v) Core capacity policy stimulated state-owned corporation (including joint- 
venture) to base on independent innovation and got ride of dependence on foreign technology, new industry-schoolinstitute-user platform provide study resource and technology support to them, and market buyer's power of core capacity policy encouraged them to develop China's $3 \mathrm{G}$ system. New platform and buyer's power also benefited for independent development mode of individually-run enterprises.

2) Causal loop diagrams [36] of technology development route for each group of enterprises are shown in fig. 3. i) Jointventure: The joint-venture was in enhanced circle of dependence on foreign technology, acquirement of new technology (limited innovation), rise of static capacity. Though platform could reduce the reliance, but policies in prior two phases intensified the reliance directly or indirectly. Only in the $3^{\text {rd }}$ phase, the policy prompted independent development capacity by visibility and market buyer's power. ii) State-owned corporations: The two state-owned corporations were in enhanced circle of little or some dependence on foreign technology, independent or cooperation development and rise of dynamic capacity. In creasing technology innovation capacity, Datang did better than Potevio because the latter went along some crooked road in former two phases.

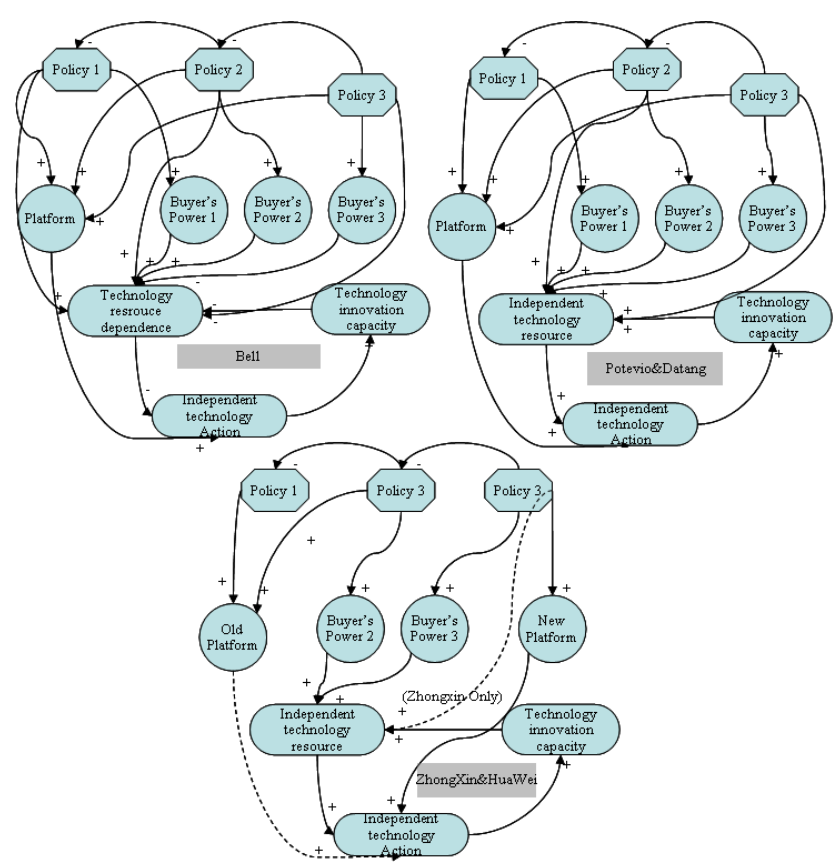

Note: 1) Broken line represents indirect or restricted function. 2) Policy 1 to 3 represent government policies in Phase 1 to 3 respectively. 3) Buyer's power 1 to 3 represent respective type of policy's market buyer's power in Phase 1 to 3 . 4) Old platform means platform of P\&T system, and new platform means platform of TD Industry Alliance.

Fig. 3 Causal loop diagrams of technology development route of five enterprises in three phases

iii) Individually-run enterprises: The two individually-run corporations were in enhanced circle of weak external technology resource and strong internal technology resource, independent development, rise of dynamic capacity. Platform improved their source of study directly or indirectly. Market buyer's power in the latter two phases fixed existing mode. Feeblish state-owned factor, instead, caused their independent and comprehensive development of technology capacity. Known from fig. 3, enhanced circle of resource, conduct and capacity could lead to that technology development action and technology innovation capacity moved in single-direction, which stablished presented mode and formed alignment effect; core capacity policy could break dependence mode with help of multiple means; State-owned factor exerted leading function in technology innovation obviously (3).

Above conclusions show that ownership exerted complicated function ("effect") through multiple approaches ("multiple-way") in latecomer's technology catch-up process. It can be summed up to be following characters. i) Effect happened through direct or indirect ways, in which the former included natural gift and visibility influence, the latter included industry-school-institute-user platform and market buyer's power. ii) Effect exerted positive function to improve technology innovation capacity and also negative function to weaken it. Function character of visibility relied on practical scenes. On natural gift, three-function division in period of planning economy led to imbalance of capability of stateowned enterprises, which had negative effect obviously. Industrial platform mainly brought positive function on latecomers. Known by above results, first, ownership factor facilitated reciprocal relationship between government and state-owned corporations, in which enterprises afforded policy responsibilities to meet the needs of government to participate and intervene economy, and government provided resource to enterprises for their need of resource dependence; Second, ownership indirectly facilitated exchange relation between government and individually-run enterprises, in which the former mobilized the latter by resource such as technology and market. In this process, government realize needs of intervening economy while it fulfilled enterprises' benefit.

TABLE VI Summary table of ownership, technology catch-up performance and technology innovation capacity performance

\begin{tabular}{|c|c|c|c|}
\hline CP & $\begin{array}{c}\text { Evaluation: } \\
\text { (State-owned) } \\
\text { ownership factor }\end{array}$ & $\begin{array}{c}\text { Evaluation: } \\
\text { Technology catch-up } \\
\text { performance }\end{array}$ & $\begin{array}{c}\text { Evaluation: } \\
\text { Technology innovation } \\
\text { capacity performance }\end{array}$ \\
\hline BL & 3 & 3 & 2 \\
\hline PT & 4 & 2 & 2 \\
\hline DT & 4 & 4 & 4 \\
\hline ZX & 2 & 2 & 4 \\
\hline HW & 1 & 2 & 3 \\
\hline
\end{tabular}

Note: 1) 1-4 in EV columns means lowest, lower, larger, largest respectively.

Based on former evaluations, the summary can be gotten in TABLE VI. Enterprises with significant state-owned ownership showed obvious industry technology promotion function (Technology catch-up performance), but also obvious inferior position in technology innovation capacity performance. The reasons are as below. First, State-owned enterprises possessed imbalanced gift and relied on policy resource to fill the gap. Individually-run enterprises started 
from scratch without reliable external resources, they per contra emphasized independent and comprehensive development. Second, State-owned enterprises afforded responsibility in intervening and participating economy of government. Individually-run enterprises could focus on its own objects and made full use of technology spill over. Third, visibility problem in corporation governance led to inclination of state-own enterprises on technology catch-up performance and neglect of capacity building performance (4); Individuallyrun enterprises emphasized both technology acquirement and capacity building up.

\section{B. Theoretical Significance}

i) This research extends eyes on entire industry chain, increases distinguishable granularity of ownership difference, and constructs logic analysis framework on mainstream theories, which inaugurates new visual angle and complements new means for research on ownership and technology catchup. Consequently, it raises theory validity in explaining catchup conduct and effect for latecomers with complicated ownership under transition economy. ii) This research enriches external control perspective of organization of resource dependence theory. Ownership factor is a concealed dimension of enterprises embedded in environment, which builds a meshwork among relevant organizations with interest relations: Reticle is ownership, knot is organization such as enterprise, and handle is government who defines and controls the essence and border of the organization relation. Stateowned enterprises can make use of ownership relation to persuade government to exert its force to change the dependence relation with other organizations, and government provides this kind of force in exchange for participating and intervening economy. Pfeffer and Salanick considered that more and more complicated needs to manage environment could urge enterprises to depend on regulation and political negotiation instead of natural market power [25]. Obviously, ownership factor enhanced this inclination. iii) This research enriches visibility perspective of corporation governance. First, it clarifies relation between visibility and visibleness. Time visibleness and shape visibleness codetermine high or low of visibleness, which can influence visibility next. Second, subject category is expanded. Besides officials who manage state-owned enterprises, other owners, industry officials in charge and resource suppliers are all brought into this subject category. Finally, degree and direction of visibility are determined by information dissymmetry, visibility and subject's preference, and influence power of visibility is determined by importance of subject.

\section{Management and Policy Significance}

First, in order to avoid trap of resource dependence, while procuring resource to solve short-term difficulties, stateowned enterprises should emphasize dynamic capacity establishment to support long-term development. They should restraint impulsion to eager for quick success and instant benefit for visibility, and pay attention to the translation of external resource to internal resource. Internal management mechanism should be optimized to help transition of static capacity to dynamic capacity. Second, state contributors should raise visibility on dynamic capacity establishment of their enterprises, especially when state-owned enterprises have been transferred from industry management department to state-owned property management department (5). For example, the latter can invite internal or external industry experts to help to establish, evaluate and assess measurement indexes, level and performance of technology dynamic capacity of state-owned corporations respectively. Third, while providing support of external resources to state-owned enterprises, government should connect force of support with dynamic capacity establishment to prevent external resource dependence of enterprises. Fourth, government is responsible for establishing public platform by which enterprises can increase their dynamic capacity.

\section{Acknowledgment}

Thanks Dr. Wang Qin in CASS for his good suggestion on this paper. The author takes sole responsibility for his views.

\section{Notes}

(1) Concept of alignment effect here is borrowed from biology in which it means that structures with same function and different source become similar with each other during acclimation. Here this word indicates that the three parts of the circle is inclined to strengthen present technology development mode, i.e. consilient function which makes present mode more stable.

(2) According to senior professionals from one telecom operator, from later 1990s to early 2000s, there was large distance between domestic GSM equipment and foreign GSM equipment, e.g. in coverage distance. Large scale of business usage of domestic GSM product needed country's great support on market. It would be very difficult for individually-run enterprises or state-owned enterprises to grow in this industry without government's support.

(3) For example, Government promoted technology spill over through Shanghai Bell's Project and Datang's project, applied market buyer's power through governanced telecom operators, and led establishment of industry-school-institute-user platform in order to promote establishment of technology innovation system.

(4) For example, Datang relied heavily on external resource in production, sale and service.

(5) Unprofessional state contributors from exterior of telecom industry have no industry specific knowledge on the dynamic capacity, and they may lack capacity of judgment on the feasibility and validity of decision of state-owned enterprises.

\section{References}

[1] L. Kim, "Stages of development of industrial technology in a developing country: a model", Research Policy, Vol.9, pp.254 277. 1980.

[2] A.-H. Amsden, "Asias' next giang: South Korea and late industrialization", New York: Oxford University Press, 1989.

[3] M. Hobday, "East asian latecomer firms: learning the technology of electronics", World Development, Vol.23, pp.1171 1193, 1995.

[4] X.-B. Shen, "The Chinese road to high technology - A study of telecommunications switching technology in the economic transition", Macmillan Press Ltd. McGraw Hill, 1999.

[5] J.-X. Liu and Y. Wang, "Technical factor analysis of Chinese telecom manufacturing in technology study and catch-up", Innovation and Undertaking-starting Management, pp. 1-22, 2008. 
[6] Z.-G. Yang, "Study and catch-up of complicated technology-—A case of Chinese telecom manufacturing", Beijing: Intellectual Property Rights Press, 2008.

[7] J. Tan, "Innovation and risk-taking in a transitional economy: A comparative study of Chinese managers and entrepreneurs", Journal of Business Venturing, vol.16, pp.359 376, 2001.

[8] J. Tan, "Impact of ownership type on enivronment-strategy linkage and performance: Evidence from a transitional economy", Journal of Management Studies, vol.39, pp.333 354, 2002.

[9] M.-W. Peng, J. Tan and T.-W. Tong, "Ownership types and strategic groups in an emerging economy", Journal of Management Studies, vol.41, pp.1105 1129, 2004.

[10] J. Cai, and A. Tylecote, "Corporate governance and technological dynamism of Chinese firms in mobile telecommunications: A quantitative study", Research Policy, vol.37, pp.1790 1811, 2008.

[11] S.-S. Jiang, L.-M. Gong and J. Wei, "The path to the catch-up of the innovative ability of the late comers of enterprises in the transitional economy: Comparing SOE with POE", Management World, no.12, pp. 96-115, 2011.

[12] R. Gulati, and M. Sytch, "Dependence asymmetry and joint dependence in interorganizational relationships: Effects of embeddedness on a manufacturer's performance in procurement relationships", Administrative Science Quarterly, vol.52, pp.32 69, 2007.

[13] T. Casciaro and M.-J. Piskorski, "Power imbalance, mutual dependence and constraint, absorption: A close look at resource dependence theory", Administrative Science Quarterly, vol.50, pp.167 199, 2005.

[14] OECD, "Industrial competitiveness directorate for science, technology and industry", OECD: Paris, 1996.

[15] W.-H. Schacht, "Industrial competitiveness and technological advancement: Debate over government policy, Congressional Research Serivce: Washington, DC., 1997.

[16] L. Kim, "Building technological capability for industrialization: Analytical frameworks and Korea's experience", Industrial and Corporate Change, vol. 8, no. 1, pp. 111-136, 1999.

[17] N. Ariffin, and P.-N. Figueiredo, "Technological capability building and innovation in the electronics industry: Eivdence from manaus-final report", Research Programme on Technological Learning and Competitive Performance, Rio de Janeiro: EBAPE-FGV, Manaus: ISAE/FGV. Mimeo, 79 pp, 2001.

[18] M. Bell and K. Paivtt, "Technological accumulation and industrial growth-contrasts between developed and developing countries", Industrial and corporate change, vol. 2, no. 2, pp. 157-210, 1993.

[19] L. Kim, "Imitation to innovation: The dynamics of Korea's technological learning”, Boston, MA: Harvard Business School Press, 1997.

[20] Y.-G. Xiao, A. Tylecote, J.-J. Liu, "Thirty years' evolution of technological capabilities and competitive advantage in a Chinese state- owned equipment manufacturer: A corporate governance perspective", IV Globelics Conference at Mexico City, September 22-24, 2008.

[21] H. Itami and T. W. Roehl, "Mobilizing inivsible assets", Cambridge, MA:Harvard Univ Press, 1987.

[22] J. G. Chen and Q. H. Huang, "Comparison and improvement of governance structure of different ownership enterprises in China", China Industrial Economy, no. 7, pp. 23-30, 2001.

[23] M. Jensen and W. Meckling, "Theory of firm: managerial behaviour, agency costs and ownership structure", Journal of Financial Economics, vol.3, pp.305 360, 1976 .

[24] A. Tylecote and P. Ramirez, "Corporate governance and innovation: The Uk compared with the Us and 'Insider' economies", Research Policy, vol.35, pp.160 180, 2006.

[25] J. Pfeffer and G.-R. Salancik, "The external control of organizations: A resource dependence perspective", NY: Harper and Row, 2003.

[26] R.-K. Yin, "Case study research: design and methods", Chongqing: Chongqing University Press, 2010.

[27] B.-G. Glaser and A.-L. Strauss, "The discovery of grounded theory: Strategies for qualitative research", Chicago, Aldine Publishing Company, 1967.

[28] W. Wei, "Research on enterprise political resource, tactics, performance and their relations in China's environment", Management World, no. 2, pp. 95-109, 2006.

[29] S. J. Huang and J. Yu, "The nature, objectives and social responsibility of state-owned enterprises", China Industrial Economy, no.2, pp. 68-76, 2006.

[30] J. C. Wu and G. H. Xi, "Reform, open and innovation--Development route of Shanghai Bell", Beijing: People Press, 2008

[31] Q. Z. Zhang, "Potevio. Made in China: China Potevio's existent environment and development tactic", Beijing: China Truth-Telling Press, 2000.

[32] J. L. Li, "TD-SCDMA provides good opportunity for development of China's mobile communication", Mobile Communication, no. 8, 2004

[33] S. H. Li, "TD-SCDMA-the 3rd generation mobile communication system standard", Datang Mobile Communication Equipment Corporation, 2002.

[34] Electronics industry yearbook compilation committee, "China Electronics Industry Year book", Beijing: Publishing House of Electronics Industry, 2001-2004.

[35] Information industry yearbook compilation committee, "China Information Industry Year book", Beijing: Publishing House of Electronics Industry, 2005-2008.

[36] J.-D. Sterman, "Business dynamics: Systems thinking and modeling for a complex world”, New York: Irwin, McGraw Hill, 2000. 